\title{
GENESIS AND CHARACTERISTICS OF SOILS OF THE SANTANAMOUNTAIN RANGE IN THE SERIDÓ REGION, RIO GRANDE DO NORTE, BRAZIL ${ }^{1}$
}

\author{
PHÂMELLA KALLINY PEREIRA FARIAS ${ }^{2 *}$, CAROLINA MALALA MARTINS SOUZA ${ }^{2}$, JEANE CRUZ \\ PORTELA $^{2}$, ISADORA NAYARA BANDEIRA MEDEIROS DE MOURA ${ }^{2}$, ANA CARLA RODRIGUES DA SILVA ${ }^{3}$
}

\begin{abstract}
Rio Grande do Norte has mountain formations with edaphoclimatic conditions different from those predominating in the state, presenting deeper,acid soils, and milder climate. Among these formations, is the Santana mountain range, which is part of the Serra do Martins Formation. The objective of this work was to interpret the pedogenesis of the representative soils of the Santana mountain range through morphological, physical, and chemical characterizations of soil profiles and evaluate the effect of these attributes on the distribution of pedological forms along the landscape using multivariate analysis. Morphological, physical, and chemical analyses of seven soil profiles of the Santana mountain range were performed. The soils were classified according to the Brazilian Soil Classification System and the data subjected to multivariate analysis. The representative soil classes found were: LATOSSOLO AMARELO Distrófico argissólico; LATOSSOLO AMARELO Eutrófico argissólico; NEOSSOLO QUARTZARÊNICO Órtico típico; NEOSSOLO LITÓLICO Eutrófico fragmentário; NEOSSOLO REGOLÍTICO Eutrófico típico and CAMBISSOLO HÁPLICO Tb Eutrófico léptico. According to the analysis of the morphological attributes, the parent material had great influence on the formation of the different soil classes found in the Santana mountain range. The soil textural classes varied from sand to sandy clay loam. According to the analysis of the chemical attributes, the soil profiles presented acid reaction, great variation of base saturation, and low electrical conductivity. The multivariate analysis established groups of representative soil profiles of the Santana mountain range through the distinction of their physical and chemical attributes, mainly of subsurface diagnostic horizons.
\end{abstract}

Keywords: Desilication. Pedogenic processes. Sedimentary rocks.

\section{CARACTERIZAÇÃO E GÊNESE DE SOLOS DA SERRA DE SANTANA, SERIDÓ POTIGUAR}

RESUMO - O Rio Grande do Norte possui formações serranas que diferem das condições edafoclimáticas predominantes no estado, apresentando solos mais profundos, ácidos e clima mais ameno. Dentre estas formações, destaca-se a Serra de Santana, que está inserida na Formação dos Martins. Com isto, objetivou-se neste trabalho interpretar a pedogênese dos solos representativos da Serra de Santana através da caracterização morfológica, física e química de perfis de solos e relacionar a influência de tais atributos na distribuição das pedoformas ao longo da paisagem, utilizando ferramentas de análise multivariada. Foram realizadas análises morfológicas, físicas e químicas de sete perfis de solos que compõem a Serra de Santana, os quais foram classificados de acordo com o Sistema Brasileiro de Classificação do Solo e os dados submetidos a análise multivariada. As classes de solos representativas foram classificadas como: LATOSSOLO AMARELO Distrófico argissólico; LATOSSOLO AMARELO Eutróficoargissólico; NEOSSOLO QUARTZARÊNICO Órtico típico; NEOSSOLO LITÓLICO Eutrófico fragmentário; NEOSSOLO REGOLÍTICO Eutrófico típico e CAMBISSOLO HÁPLICO Tb Eutróficoléptico. Ao observar os atributos morfológicos percebeu-se que houve grande influência do material de origem na distinção das principais classes de solo encontradas na Serra. A classe textural dos perfis variou de areia a franco-argilo-arenosa. Em relação aos atributos químicos, todos os perfis apresentaram reação ácida, grande variação de saturação por bases entre os perfis e baixos valores de condutividade elétrica. A análise multivariada estabelece grupos de perfis de solos representativos da Serra de Santana através da distinção de atributos físicos e químicos principalmente dos horizontes subsuperficiais diagnósticos.

Palavras-chave: Latolização. Processos pedogenéticos. Rochas sedimentares.

\footnotetext{
${ }^{*}$ Corresponding author

${ }^{1}$ Received for publication in 05/08/2017; accepted in 03/08/2018.

Part of the first author's Master's thesis.

${ }^{2}$ Center for Agrarian Sciences, Universidade Federal Rural do Semi-Árido, Mossoró, RN, Brazil; phamellakalliny@hotmail.com - ORCID: 0000-0002-5388-4204, carolmalala@ufersa.edu.br - ORCID: 0000-0002-9553-9126, jeaneportela@ufersa.edu.br - ORCID: 0000-00029207-5530, isadora.med@hotmail.com - ORCID: 0000-0002-9644-644X.

${ }^{3}$ Department of Soil Science, Universidade Federal do Ceará, Fortaleza, CE, Brazil; anacrodrigues9148@hotmail.com - ORCID: 00000003-4021-9712.
} 


\section{INTRODUCTION}

The state of Rio Grande do Norte, Brazil, has a geomorphological mosaic combining plain landscapes of the semi-arid region and mountain formations. These formationsare sparse considering the prevailing edaphoclimatic conditions of the state but are important landscapes due to their contribution for the understanding of the local pedogenesis. Moreover, the agricultural production of these areas is important for the state's economy. These areas have usually deeper, acid soils associated with a milder climate.

Among these formations, is the Santana mountain range, which is part of the Serra do Martins Formation. It denotes a more extensive sedimentary cover that was eroded in the past. Rocksof approximately 30 million years old (Paleogene period) from the Serra do Martins Formation predominate in the Santana mountain range, presenting medium to conglomerate arenites, clayey arenites, and laterite crust with quartz pebbles (ANGELIM et al., 2006).

This formation can also be defined as part of the SertanejosResidual Plateaus that represent high altitude reliefs in the form of plateaus or mountainous ranges, presenting in general more resistant rocks that are remnants of the generalized leveling that occurred in the Paleogene period. They appear as residual features among the vast flatland of the Sertaneja Depression, concentrating on the southwest and central region of the state, with some units in the Serido region, where the Santana mountain range is located. Pedogenetic processes in the Santana mountain range were strongly influenced by its sedimentary parent material, and the wetter climatic condition, and flat relief existing throughout the Serra do Martins formation.

The geological composition affected intensely the formation of the representative soils of the Santana mountain range. According to the interpretation of the composition of arenites that predominate throughout these plateaus, the cementing matrix of this type of rock may have been different in different points since the climatic condition and relief of the region are homogeneous. Therefore, the main factor that caused the formation of different soil classes was the parent material. Latossolos were formed in areas with a cementing matrix richer in iron and finer granulometry, and Neossolos were formed in areas with siliceous matrix and coarser granulometry. In this context, the objective of this work was to interpret the pedogenesis of the representative soils of the Santana mountain range through morphological, physical, and chemical characterizations of its soil profiles and evaluate the effect of these attributes on the distribution of pedological forms along the landscape using multivariate analysis.

\section{MATERIAL AND METHODS}

The Santana mountain range microregion is in the centerstate of Rio Grande do Norte, Brazil. It encompasses seven municipalities, namely Bodó, Cerro Corá, Florânia, Lagoa Nova, São Vicente, Santana do Matos, and Tenente Laurentino Cruz. The climate of the Santana mountain range is BSh, according to the updated Köppen classification (ALVARES et al., 2013), presenting a local steppe climate, with annual average precipitation of 615 $\mathrm{mm}$, and annual average air temperature of $23.7^{\circ} \mathrm{C}$, with minimum of $21.8^{\circ} \mathrm{Cin}$ July and maximum of $25.2^{\circ} \mathrm{C}$ in January. The native vegetation is basically composed of semideciduous seasonal forest, with significant leaf loss in the dry period, especially by the arboreal stratum (IBGE, 2012). The Santana mountain range microregion is in a transition relief between surfaces with different altitudes and slopes of approximately 400 meters; it consists of a fragmented plateau of a past high altitude surface layered, in the Paleogene period, by laterized arenites of the Serra dos Martins Formation that present altitudes of 700 to $800 \mathrm{~m}$ and are abruptly delimited by erosive escarpments (NASCIMENTO; FERREIRA, 2010).

Seven representative soil profiles of the Santana mountain range were selected based on a soil survey carried out by Ernesto Sobrinho et al. (1987) (Figure 1).

All horizons of the soil profiles were collected and described according to Santos et al. (2013a) and classified up to the $4^{\text {th }}$ categorical level based on the Brazilian Soil Classification System (Santos et al., 2013b). The morphological evaluations involved profile and environmental characteristics according to Santos et al. (2013a).

The physical analyzes were performedon airdried fine earth with three replications using the same sample. The granulometry was evaluated using the pipette method with chemical dispersant (sodium hexametaphosphate) and distilled water in $20 \mathrm{~g}$ of airdried fine earth, under slow mechanical agitation (Wagner, $50 \mathrm{rpm}$ ) for 16 hours (DONAGEMA et al., 2011). The soil density analysis was performed using the test tube method due to the sandy texture of the surface horizons and more dense consistency of the subsurface horizons, which made it impossible the collection of undisturbed soil samples, according to the methods described in Donagema et al. (2011).

Chemical analyzes were performed using airdried fine earth samples, with three replications, according to the methods described in Donagema et al. (2011). It consisted of evaluations of the soil $\mathrm{pH}$ in water and in $\mathrm{KCl}\left(1: 2.5 \mathrm{mv}^{-1}\right)$; extraction of available $\mathrm{P}, \mathrm{Na}^{+}$, and $\mathrm{K}^{+}$by Mehlich-1, with determination of available $\mathrm{P}$ contents by colorimetry, and $\mathrm{Na}^{+}$and $\mathrm{K}^{+}$contents by flame photometry; extraction of exchangeable cations of $\mathrm{Ca}^{2+}, \mathrm{Mg}^{2+}$, and $\mathrm{Al}^{3+}$ with $\mathrm{KCl} 1 \mathrm{~mol} \mathrm{~L}^{-1}$, with determination of 
$\mathrm{Ca}{ }^{2+}$ and $\mathrm{Mg}^{2+}$ contents by atomic absorption spectrophotometry, and $\mathrm{Al}^{3+}$ contents by titration; $\mathrm{H}^{+}$ was extracted with calcium acetate $1 \mathrm{~mol} \mathrm{~L}^{-1} \mathrm{pH} 7.0$ and determined by titration. Total organic carbon was determined by wet oxidation using $0.167 \mathrm{~mol} \mathrm{~L}$ ${ }^{1}$ of potassium dichromate (YEOMANS; BREMNER, 1988).

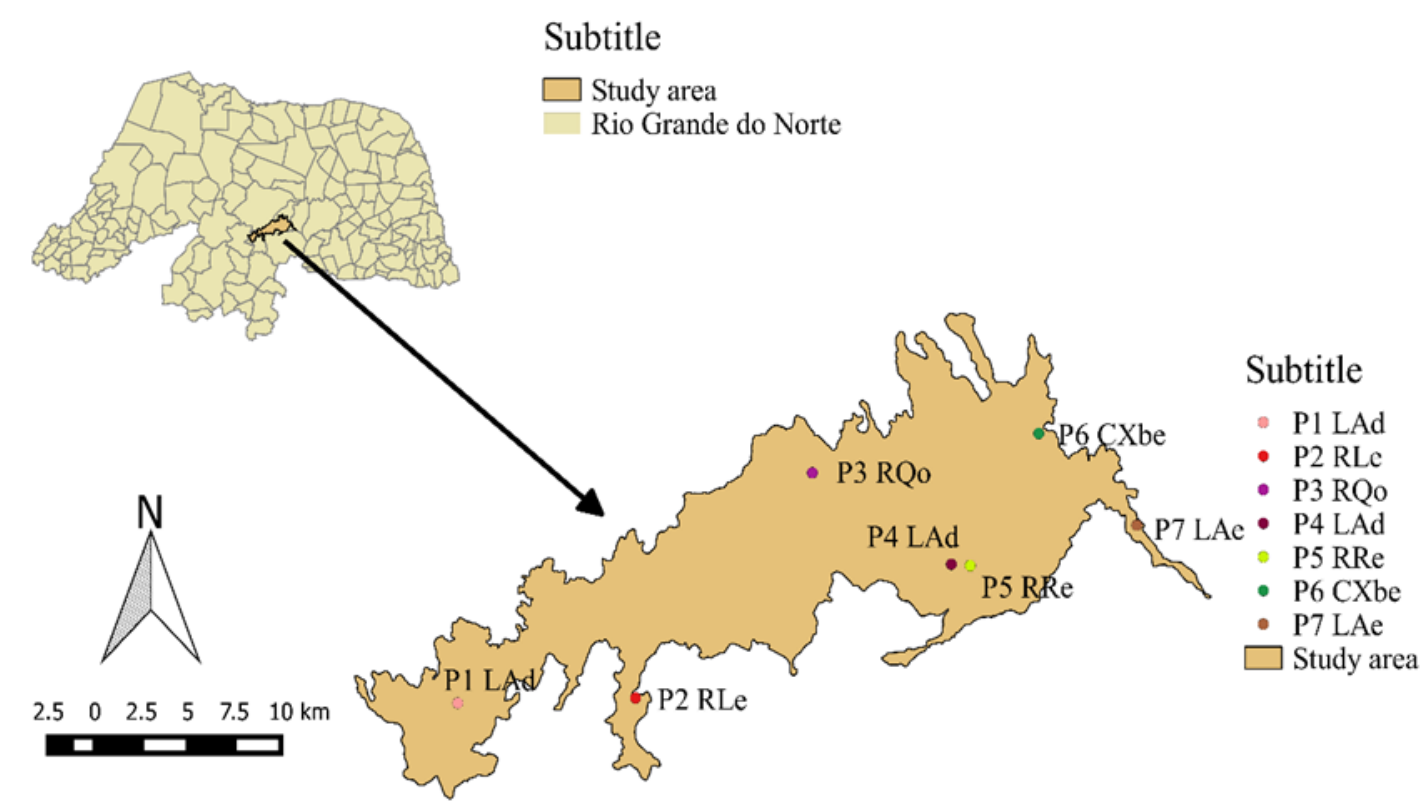

WGS 84 - UTM 24S

Author: Phâmella Farias

Figure 1. Location of the soil profiles evaluated in the Santana mountain range, Rio Grande do Norte, Brazil.

The following indices were obtained based on the chemical analyzes: sum of bases, effective cation exchange capacity, cation exchange capacity at $\mathrm{pH}$ 7.0, base saturation, exchangeable aluminum saturation, and exchangeable sodium percentage. These indices were determined according to the Embrapa's manual of methods for soil analysis (DONAGEMA et al., 2011).

The soil profiles were distinguished using the morphological description through field observations, and multivariate analysis techniques, especially the Principal Component Analysis, using the Statistica 7.0 software (STATSOFT, 2004), considering the physical and chemical attributes of the soil as variables.

\section{RESULTS AND DISCUSSION}

The soil attributes indicate great influence of the parent material on the formation of the different soil classes found, since the other soil formation factors were relatively homogeneous throughout the mountain range. Three representative soil classesLatossolo, Neossolo and Cambissolo- were classified up to the $4^{\text {th }}$ categorical level, according to Santos et al. (2013b). The Latossolo order was represented by three soil profiles: LATOSSOLO AMARELO Distrófico argissólico (P1 and P4), and LATOSSOLO AMARELO Eutrófico argissólico (P7). The Neossolo order was represented by three soil profiles: NEOSSOLO LITÓLICO Eutrófico fragmentário $\quad(\mathrm{P} 2), \quad$ NEOSSOLO QUARTZARÊNICO Órtico típico (P3), and NEOSSOLO REGOLÍTICO Eutrófico típico (P5). One soil profile of the Cambissoloorder was representative of the pedological forms and classified as CAMBISSOLO HÁPLICO Tb Eutrófico léptico (P6).

According to the interpretation of these soil classes, the composition of the arenites probably has a resistance matrix that varies according to the drainage points of the mountain range, since the climatic condition and relief of the region are homogeneous, with low variations in altitude between the profiles (Table 1).Thus, the parent material is probably the main factor that distinguished the soil classes, forming Latossolos Amarelos in areas with a cementing matrix richer in iron and finer granulometry, Neossolos Quartzarênicos and Regolíticos in areas with siliceous matrix and coarse granulometry, and Cambissolos Háplicos and Neossolos Litólicos in an area close to the edge of the mountain range with lower water infiltration. 
P. K. P. FARIAS et al.

Table 1. Morphological attributes of representative soil profiles of the Santana mountain range, Rio Grande do Norte, Brazil.

\begin{tabular}{|c|c|c|c|c|c|c|c|c|}
\hline $\begin{array}{l}\text { Horizon (Depth) } \\
\text { Cm }\end{array}$ & $\begin{array}{l}\text { Altitude } \\
\text { (m) }\end{array}$ & $\begin{array}{l}\text { Color } \\
\text { (moist) }\end{array}$ & $\begin{array}{l}\text { Parent material } \\
\text { (Geological }\end{array}$ & Structure & \multicolumn{3}{|c|}{ Consistency } & $\mathrm{T}$ \\
\hline & & & & & Dry & Moist & Wet & \\
\hline \multicolumn{9}{|c|}{ Profile1- LATOSSOLO AMARELO Distrófico argissólico (LAd) } \\
\hline $\mathrm{A}(0-20)$ & \multirow{4}{*}{739} & $10 \mathrm{YR} 3 / 2$ & & $2 \mathrm{MG} \mathrm{Gr}$ & $\mathrm{Ma}$ & $\mathrm{MFr}$ & LgPlLgPe & $\overline{\mathrm{Pd}}$ \\
\hline $\mathrm{AB}(20-62)$ & & $2.5 \mathrm{Y} 4 / 4$ & Arenite & $1 \mathrm{MG} \mathrm{Gr}$ & $\mathrm{LgD}$ & MFr & LgPlLgPe & $\mathrm{Pd}$ \\
\hline BA (62-99) & & $2.5 Y 5 / 3$ & (Paleogene) & $1 \mathrm{MG} \mathrm{Gr}$ & LgD & MFr & $\mathrm{Pl} \operatorname{LgPe}$ & $\mathrm{Pd}$ \\
\hline Bw (99-187) & & $2.5 \mathrm{Y} 5 / 3$ & & $1 \mathrm{MG} \mathrm{Gr}$ & LgD & MFr & $\mathrm{PlPe}$ & $\mathrm{Pd}$ \\
\hline \multicolumn{9}{|c|}{ Profile2 - NEOSSOLO LITÓLICO Eutrófico fragmentário (RLe) } \\
\hline Ap $(0-9)$ & \multirow{2}{*}{670} & $2.5 \mathrm{Y} 3 / 3$ & Arenite & 2 MG Bla & $\mathrm{D}$ & $\mathrm{Fr}$ & LgPlLgPe & $\overline{\mathrm{Pg}}$ \\
\hline $\mathrm{C}(9-22)$ & & $2.5 Y 5 / 4$ & (Paleogene) & $1 \mathrm{MG} \mathrm{Gr}$ & $\mathrm{LgD}$ & MFr & LgPlLgPe & Pc \\
\hline \multicolumn{9}{|c|}{ Profile3 - NEOSSOLO QUARTZARÊNICO Órtico típico (RQo) } \\
\hline Ap (0-26) & \multirow{4}{*}{685} & $10 \mathrm{YR}^{3} / 4$ & & $1 \mathrm{GMBlsGr}$ & $\mathrm{Ma}$ & $\mathrm{MFr}$ & NPINPe & $\overline{\mathrm{Pd}}$ \\
\hline $\mathrm{AC}(26-64)$ & & $10 \mathrm{YR} 5 / 6$ & Arenite & $1 \mathrm{MGBlsGr}$ & $\mathrm{Ma}$ & MFr & NPINPe & $\mathrm{Pd}$ \\
\hline C1 (64-116) & & $10 \mathrm{YR} 4 / 6$ & (Paleogene) & 1MGBlsGr & $\mathrm{Ma}$ & MFr & NPINPe & $\mathrm{Pd}$ \\
\hline $\mathrm{C} 2(116-181)$ & & 10YR 5/6 & & $1 \mathrm{MGBlsGr}$ & $\operatorname{LgD}$ & MFr & NPlLgPe & $\mathrm{Pd}$ \\
\hline \multicolumn{9}{|c|}{ Profile4 - LATOSSOLO AMARELO Distrófico argissólico (LAd) } \\
\hline $\mathrm{A}(0-16)$ & \multirow{4}{*}{701} & $2.5 \mathrm{Y} 3 / 2$ & & $2 \mathrm{MGr}$ & LgD & $\mathrm{MFr}$ & NPINPe & $\overline{\mathrm{Pg}}$ \\
\hline $\mathrm{AB}(16-52)$ & & $2.5 \mathrm{Y} 4 / 4$ & Arenite & 2PMGr & $\mathrm{LgD}$ & MFr & LgPlLgPe & $\mathrm{Pd}$ \\
\hline Bw1 (52-93) & & $2.5 \mathrm{Y} 4 / 4$ & (Paleogene) & $2 \mathrm{GGr}$ & LgD & MFr & LgPlLgPe & $\mathrm{Pd}$ \\
\hline Bw2 (93-168) & & $2.5 \mathrm{Y} 4 / 4$ & & 2MGGr & $\mathrm{LgD}$ & $\mathrm{MFr}$ & LgPlLgPe & $\mathrm{Pd}$ \\
\hline \multicolumn{9}{|c|}{ Profile5 - NEOSSOLO REGOLÍTICO Eutrófico típico (RRe) } \\
\hline Ap (0-14) & \multirow{4}{*}{701} & $2.5 \mathrm{Y} 4 / 2$ & & 2MBlsGr & $\mathrm{D}$ & $\mathrm{Fi}$ & NPINPe & $\overline{\mathrm{Pd}}$ \\
\hline $\mathrm{C}_{1}(14-38)$ & & $2.5 Y 5 / 2$ & Arenite & 2MGGr & $\operatorname{LgD}$ & Fr & NPILgPe & $\mathrm{Pd}$ \\
\hline $\mathrm{C}_{2}(38-96)$ & & $2.5 \mathrm{Y} 6 / 2$ & (Paleogene) & 2MGGr & LgD & Fr & LgPlLgPe & Pd \\
\hline $\mathrm{C}_{3}(96-172)$ & & $2.5 \mathrm{Y} 6 / 2$ & & 2PMBls Gr & $\mathrm{LgD}$ & $\mathrm{MFr}$ & LgPlPe & $\mathrm{Pd}$ \\
\hline \multicolumn{9}{|c|}{ Profile 6 - CAMBISSOLO HÁPLICO Tb Eutrófico léptico (CXbe) } \\
\hline $\mathrm{A}(0-11)$ & \multirow{4}{*}{713} & $10 \mathrm{YR} 4 / 4$ & & $21 \mathrm{GMBls} \mathrm{Gr}$ & $\mathrm{Ma}$ & $\overline{F r}$ & LgPINPe & $\overline{\mathrm{Pc}}$ \\
\hline $\mathrm{AB}(11-23)$ & & 10YR 4/6 & Arenite & 2 GM Bla & $\mathrm{Ma}$ & $\mathrm{Fr}$ & PlLgPe & $\mathrm{Og}$ \\
\hline $\mathrm{Bi}(23-52)$ & & 10YR 5/6 & (Paleogene) & $21 \mathrm{G} \mathrm{Bls}$ & $\mathrm{Ma}$ & $\mathrm{Fr}$ & LgPlLgPe & $\mathrm{Pg}$ \\
\hline $\mathrm{Cr}(52-66)$ & & 10YR 5/8 & & $21 \mathrm{G} \mathrm{Bls}$ & $\mathrm{LgD}$ & $\mathrm{Fr}$ & LgPlLgPe & $\mathrm{Pg}$ \\
\hline \multicolumn{9}{|c|}{ Profile7 - LATOSSOLO AMARELO Eutrófico argissólico (LAe) } \\
\hline & \multirow{4}{*}{674} & $10 \mathrm{YR} 4 / 6$ & & 1PMBlsGr & LgD & $\mathrm{MFr}$ & LgPINPe & $\overline{\mathrm{Pg}}$ \\
\hline $\mathrm{AB}(22-61)$ & & $10 \mathrm{YR} 5 / 6$ & Arenite & 2PMBlsGr & LgD & MFr & LgPlLgPe & $\mathrm{Pd}$ \\
\hline $\mathrm{Bw}_{1}(61-114)$ & & 10YR 5/8 & (Paleogene) & $21 \mathrm{GM} \mathrm{Gr}$ & LgD & MFr & LgPlPe & $\mathrm{Pd}$ \\
\hline $\mathrm{Bw}_{2}(114-167)$ & & 10YR 5/8 & & $2 \mathrm{M} \mathrm{Gr}$ & $\mathrm{LgD}$ & MFr & LgPIPe & $\mathrm{Pd}$ \\
\hline
\end{tabular}

Structure: 1 = weak, 2 = moderate, $\mathrm{P}=$ small, $\mathrm{M}=$ medium, $\mathrm{G}=$ large, $\mathrm{Gr}=$ granular; $\mathrm{Bla}=$ angular blocks; $\mathrm{Bls}=$ subangular blocks; Consistency: $\mathrm{Ma}=$ soft, $\mathrm{D}=$ hard, $\mathrm{Fr}=$ friable, $\mathrm{Fi}=$ firm, $\mathrm{N}=\mathrm{No}, \mathrm{M}=$ very, $\mathrm{Lg}=$ slightly, $\mathrm{Pl}=\mathrm{plastic}, \mathrm{Pe}=$ Sticky; $\mathrm{T}=$ Transition, $\mathrm{p}=$ flat, $\mathrm{d}=$ diffuse, $\mathrm{c}=$ clear, $\mathrm{g}=$ gradual .

The soil profiles showed no significant differences in color, with shades varying from $10 \mathrm{YR}$ to $2.5 \mathrm{Y}$, showing yellow color for all horizons. Considering these values and chromas found, soils with light and greyish shades predominated in all points, except in P5, which presented low values of chroma, denoting a lower intensity of gray (Table 1). According to Ernesto Sobrinho et al. (1987), the color variation of Latossolos in the Santana mountain range (Pale to Yellow)is probably due to variations in other components of the soil. This variation can be associated to environments that present slight geomorphological variations, with soils maintaining higher moisture and consequently causing alterations in the genesis of secondary minerals, mainly iron oxides. Ernesto Sobrinho et al. (1987) also attributed the palecolor of soils to the intense deironization process, and the soil proximity to the water table, especially in the past. This proximity may explain the distinct textures of the predominant classes-Latossolos richer in clay, contributing to the maintenance of moisture, and Neosols richer in sand, accelerating the drainage process.

Most profiles presented block structures that disaggregated into granular blocks (Table 1). Latossolos cauliníticos, whose particles are surrounded by continuous dense plasma, develop a block macrostructure because of the face-to-face adjustment of kaolinite plates (FERREIRA et al., 1999). According to Silva et al. (2014), Neossolo profiles in the Santana mountain range region present structures in sub-angular and granular blocks with moderate development and classes ranging from medium to small.

The dry and moist soil consistencies ranged from soft to slightly hard, and friable to very friable, respectively, presenting a distinction in $\mathrm{P} 2$, which 
was classified as a Neossolo Litólico, and in P5, which was classified as a Neossolo Regolítico, both showing hard consistency in the surface horizon, denoting that these soils were less weathered, and the effect of cementing agents. The variation of the subsurface consistency in Latossolos occurred mainly by translocation of clay to subsurface horizons. Most horizons presented diffuse transition, which is typical of homogeneous and deep soils (Table 1).

The grain size of the profiles showed that the total sand fraction (coarse sand plus fine sand) predominated over the silt and clay fractions, varying between $593 \mathrm{~g} \mathrm{~kg}^{-1}$ (Bwhorizon of P1) and $934 \mathrm{~g} \mathrm{~kg}^{-1}$ (Aphorizon of P3) (Table 2).

Table 2. Physical attributes of representative soil profiles of the Santana mountain range, Rio Grande do Norte, Brazil.

\begin{tabular}{|c|c|c|c|c|c|c|c|}
\hline $\begin{array}{l}\text { Horizon (Depth) } \\
\mathrm{cm}\end{array}$ & $\mathrm{CS}$ & FS & Silt & Clay & $\begin{array}{l}\text { Silt/ } \\
\text { Clay }\end{array}$ & Textural class & $\begin{array}{l}\mathrm{SD} \\
\mathrm{g} / \mathrm{cm}^{3}\end{array}$ \\
\hline \multicolumn{8}{|c|}{ Profile 1 - LATOSSOLO AMARELO Distrófico argissólico (LAd) } \\
\hline $\mathrm{A}(0-20)$ & 700 & 104 & 28 & 168 & 0.16 & Sandy loam & 1.33 \\
\hline $\mathrm{AB}(20-62)$ & 567 & 137 & 30 & 266 & 0.11 & Sandy clay loam & 1.36 \\
\hline $\mathrm{BA}(62-99)$ & 457 & 140 & 35 & 368 & 0.09 & Sandy clay & 1.44 \\
\hline $\mathrm{Bw}(99-187)$ & 458 & 135 & 41 & 366 & 0.11 & Sandy clay & 1.43 \\
\hline \multicolumn{8}{|c|}{ Profile 2 - NEOSSOLO LITÓLICO Eutrófico fragmentário (RLe) } \\
\hline Ap (0-9) & 551 & 149 & 59 & 241 & 0.25 & Sandy clay loam & 1.40 \\
\hline $\mathrm{C}(9-22)$ & 464 & 155 & 78 & 303 & 0.26 & Sandy clay loam & 1.31 \\
\hline \multicolumn{8}{|c|}{ Profile 3 - NEOSSOLO QUARTZARÊNICO Órtico típico (RQo) } \\
\hline Ap $(0-26)$ & 780 & 154 & 6 & 60 & 0.10 & Sand & 1.42 \\
\hline $\mathrm{AC}(26-64)$ & 751 & 164 & 7 & 78 & 0.09 & Sand & 1.59 \\
\hline $\mathrm{C} 1(64-116)$ & 729 & 160 & 10 & 101 & 0.10 & Loamy sand & 1.55 \\
\hline $\mathrm{C} 2(116-181)$ & 677 & 174 & 16 & 133 & 0.12 & Loamy sand & 1.62 \\
\hline \multicolumn{8}{|c|}{ Profile 4 - LATOSSOLO AMARELO Distrófico argissólico } \\
\hline Ap $(0-16)$ & 747 & 154 & 20 & 79 & 0.02 & Sand & 1.56 \\
\hline $\mathrm{AB}(16-52)$ & 651 & 159 & 42 & 148 & 0.28 & Sandy loam & 1.45 \\
\hline Bw1(52-93) & 613 & 150 & 27 & 210 & 0.13 & Sandy clay loam & 1.36 \\
\hline Bw2(93-168) & 580 & 169 & 26 & 225 & 0.12 & Sandy clay loam & 1.40 \\
\hline \multicolumn{8}{|c|}{ Profile 5 - NEOSSOLO REGOLÍTICO Eutrófico típico (RRe) } \\
\hline Ap $(0-14)$ & 718 & 193 & 22 & 67 & 0.33 & Sand & 1.43 \\
\hline C1(14-38) & 686 & 174 & 19 & 121 & 0.16 & Loamy sand & 1.50 \\
\hline $\mathrm{C} 2(38-96)$ & 613 & 172 & 23 & 192 & 0.12 & Sandy loam & 1.42 \\
\hline C3(96-172) & 544 & 168 & 33 & 255 & 0.13 & Sandy clay loam & 1.38 \\
\hline \multicolumn{8}{|c|}{ Profile 6-CAMBISSOLO HÁPLICO Tb Eutrófico léptico (CXbe) } \\
\hline $\mathrm{A}(0-11)$ & 551 & 191 & 123 & 135 & 0.91 & Sandy loam & 1.41 \\
\hline $\mathrm{AB}(11-23)$ & 476 & 189 & 131 & 204 & 0.64 & Sandy loam & 1.31 \\
\hline $\mathrm{Bi}(23-52)$ & 416 & 182 & 150 & 252 & 0.59 & Sandy clay loam & 1.21 \\
\hline $\mathrm{Cr}(52-66)$ & 425 & 177 & 169 & 229 & 0.74 & Sandy clay loam & 1.22 \\
\hline \multicolumn{8}{|c|}{ Profile 7 - LATOSSOLO AMARELO Eutrófico argissólico (LAe) } \\
\hline Ap $(0-22)$ & 686 & 153 & 17 & 144 & 0.12 & Sandy loam & 1.40 \\
\hline $\mathrm{AB}(22-61)$ & 543 & 188 & 140 & 129 & 1.08 & Sandy loam & 1.44 \\
\hline Bw1(61-114) & 457 & 197 & 28 & 318 & 0.08 & Sandy clay loam & 1.42 \\
\hline Bw2(114-167) & 481 & 201 & 101 & 217 & 0.46 & Sandy clay loam & 1.41 \\
\hline
\end{tabular}

$\mathrm{CS}=$ coarse sand; $\mathrm{FS}=$ fine sand; $\mathrm{SD}=$ soil density.

Similar results of sand fraction (764.1 to $876.5 \mathrm{~g} \mathrm{~kg}^{-1}$ )were found in profiles of Neossolo Regolítico in São João, Pernambuco, Brazil (SILVA et al., 2014) and in the state of Pernambuco in five soil profiles (713 and $902 \mathrm{~g} \mathrm{~kg}^{-1}$ ) (SANTOS et al., 2012). Lower but similar contents were found in Santa Maria, Rio Grande do Sul, Brazil (533 to $805 \mathrm{~g}$ $\mathrm{kg}^{-1}$ ) (PEDRON et al., 2011). The textural class of the studied profiles ranged from sand to sandy clay loam, which is probably due to the presence of minerals that were more resistant to the weathering process.

The granulometric composition of the Latossolos presented low levels of silt, and silt to clay ratio lower than 0.7 , indicating a more intense pedogenesis, except for the transitional horizon $\mathrm{AB}$ of P7, which presented higher levels of silt, unusual in Latossolos. The clay content in the subsurface horizons of these soils exceededtheir surface contents, generating a textural gradient greater than 1.4 in all profiles of this order, fitting them into the argissólico subgroup. The high soil density found in the horizons of the profiles can be explained by the high sand content and, consequently, predominance of the quartz mineral in the solid fraction; although other mineral phases such as feldspars, chlorites and micas may also present high density. Sandy soils have higher density than clayey soils, and silty soils 
have intermediate density (LIBARDI, 2005).

According to the chemical attributes evaluated (Table 3 ), the horizons of all soil profiles have an acidic reaction, with $\mathrm{pH}$ in water of less than 7.0. The soil $\mathrm{pH}$ in water of most soil profiles was higher than those in $\mathrm{KCl}$, indicating predominance of negative charges in the exchange complex and the dystrophic character of these soils. The cation exchange capacity (CEC) were different along the horizons, which presented CEC of $3.63 \mathrm{cmol}_{\mathrm{c}} \mathrm{kg}^{-1}$ (AB horizon of P1 LAd) to $8.03 \mathrm{cmol}_{\mathrm{c}} \mathrm{kg}^{-1}$ (Ap horizon of P2RLe); these CECs are probably maintained by the predominance of negative charges along the profiles.

Table 3. Soil chemical attributes of representative soil profiles of the Santana mountain range, Rio Grande do Norte, Brazil.

\begin{tabular}{|c|c|c|c|c|c|c|c|c|c|c|c|c|c|c|c|}
\hline Hor. & $\begin{array}{c}\mathrm{pH} \\
\left(\mathrm{H}_{2} \mathrm{O}\right)\end{array}$ & $\begin{array}{c}\mathrm{pH} \\
(\mathrm{KCl})\end{array}$ & $\Delta \mathrm{pH}$ & $\begin{array}{c}\mathrm{EC} \\
(\mathrm{dS} / \mathrm{m})\end{array}$ & $\begin{array}{l}\text { TOC } \\
\mathrm{g} / \mathrm{kg}\end{array}$ & $\mathrm{K}^{+}$ & $\mathrm{Na}^{+}$ & $\mathrm{Ca}^{2+}$ & $\begin{array}{l}\mathrm{Mg}^{2+} \\
\mathrm{cmol}_{\mathrm{c}}\end{array}$ & $\mathrm{Al}^{3+}$ & $(\mathrm{H}+\mathrm{Al})$ & $\mathrm{T}$ & \multirow[t]{2}{*}{$\begin{array}{c}\mathrm{P} \\
\mathrm{mg} / \mathrm{kg}\end{array}$} & \multicolumn{2}{|c|}{$\begin{array}{l}\mathrm{V} \quad \mathrm{M} \\
-(\%)\end{array}$} \\
\hline \multicolumn{15}{|c|}{ Profile 1- LATOSSOLO AMARELO Distrófico argissólico (LAd) } & \\
\hline A & 4.51 & 3.89 & -0.62 & 0.09 & 16.70 & 0.14 & - & 0.83 & 0.36 & 0.20 & 3.68 & 5.02 & 5.01 & 28 & 13 \\
\hline $\mathrm{AB}$ & 4.18 & 3.87 & -0.31 & 0.03 & 6.21 & 0.05 & - & 0.49 & 0.36 & 0.40 & 2.73 & 3.63 & 2.69 & 25 & 31 \\
\hline $\mathrm{BA}$ & 3.75 & 3.84 & 0.08 & 0.04 & 5.06 & 0.01 & - & 1.01 & 0.42 & 0.65 & 3.05 & 4.50 & 3.09 & 32 & 31 \\
\hline $\mathrm{Bw}$ & 3.80 & 3.88 & 0.09 & 0.02 & 4.70 & 0.01 & - & 0.87 & 0.44 & 0.67 & 2.85 & 4.17 & 2.07 & 32 & 34 \\
\hline \multicolumn{16}{|c|}{ Profile 2 - NEOSSOLO LITÓLICO Eutrófico fragmentário (RLe) } \\
\hline Ap & 3.98 & 3.75 & -0.22 & 0.02 & 8.45 & 0.08 & - & 2.66 & 0.90 & 0.53 & 4.40 & 8.03 & 3.13 & 45 & 13 \\
\hline $\mathrm{C}$ & 3.78 & 3.71 & -0.07 & 0.02 & 8.47 & 0.02 & - & 2.07 & 0.36 & 0.73 & 4.58 & 7.02 & 3.82 & 35 & 23 \\
\hline \multicolumn{16}{|c|}{ Profile 3 - NEOSSOLO QUARTZARÊNICO Órtico típico (RQo) } \\
\hline Ap & 4.64 & 4.15 & -0.49 & 0.03 & 6.27 & 0.12 & - & 2.04 & 0.36 & 0.15 & 2.05 & 4.56 & 3.18 & 55 & 6 \\
\hline $\mathrm{AC}$ & 4.03 & 4.11 & 0.08 & 0.02 & 3.08 & 0.04 & - & 2.11 & 0.36 & 0.27 & 2.00 & 4.51 & 2.37 & 56 & 10 \\
\hline $\mathrm{C} 1$ & 3.90 & 4.24 & 0.34 & 0.03 & 2.02 & 0.02 & - & 2.15 & 0.41 & 0.23 & 2.15 & 4.73 & 3.36 & 55 & 8 \\
\hline $\mathrm{C} 2$ & 3.96 & 4.26 & 0.31 & 0.02 & 1.43 & 0.02 & - & 1.83 & 0.45 & 0.63 & 2.18 & 4.48 & 2.92 & 51 & 22 \\
\hline \multicolumn{16}{|c|}{ Profile 4 - LATOSSOLO AMARELO Distrófico argissólico (LAd) } \\
\hline Ap & 5.65 & 5.55 & -0.10 & 0.04 & 11.56 & 0.22 & - & 1.76 & 0.41 & 0.13 & 1.95 & 4.35 & 30.37 & 55 & 5 \\
\hline $\mathrm{AB}$ & 5.27 & 5.13 & -0.14 & 0.02 & 6.08 & 0.10 & - & 2.15 & 0.49 & 0.01 & 1.98 & 4.72 & 17.79 & 58 & 0.5 \\
\hline Bw1 & 4.22 & 4.07 & -0.15 & 0.02 & 5.72 & 0.08 & - & 1.68 & 0.47 & 0.20 & 2.54 & 4.76 & 10.92 & 47 & 8 \\
\hline Bw2 & 3.75 & 3.84 & 0.09 & 0.02 & 4.45 & 0.10 & - & 1.35 & 0.46 & 0.40 & 2.80 & 4.71 & 1.97 & 41 & 17 \\
\hline \multicolumn{16}{|c|}{ Profile 5 - CAMBISSOLO HÁPLICO Tb Eutrófico léptico (CXbe) } \\
\hline Ap & 5.48 & 4.60 & -0.88 & 0.01 & 9.26 & 0.07 & - & 3.45 & 0.41 & 0.20 & 2.40 & 6.33 & 4.56 & 62 & 5 \\
\hline $\mathrm{C} 1$ & 5.12 & 4.10 & -1.02 & 0.01 & 6.77 & 0.05 & - & 2.95 & 0.35 & 0.35 & 2.40 & 5.75 & 3.38 & 58 & 9 \\
\hline $\mathrm{C} 2$ & 4.61 & 3.98 & -0.63 & 0.01 & 5.82 & 0.02 & - & 3.15 & 0.37 & 0.52 & 2.88 & 6.41 & 3.18 & 55 & 13 \\
\hline $\mathrm{C} 3$ & 4.30 & 3.91 & -0.39 & 0.01 & 5.48 & 0.02 & - & 3.26 & 0.42 & 0.65 & 3.08 & 6.77 & 2.30 & 55 & 15 \\
\hline \multicolumn{16}{|c|}{ Profile 6 - LATOSSOLO AMARELO Eutrófico argissólico (LAe) } \\
\hline A & 6.21 & 5.53 & -0.68 & 0.09 & 11.59 & 0.06 & - & 2.12 & 0.93 & 0.10 & 2.45 & 6.43 & 12.64 & 62 & 2 \\
\hline $\mathrm{AB}$ & 5.06 & 4.30 & -0.76 & 0.04 & 5.60 & 0.08 & - & 2.57 & 0.91 & 0.82 & 3.23 & 7.62 & 4.08 & 58 & 16 \\
\hline $\mathrm{Bi}$ & 4.95 & 4.14 & -0.80 & 0.03 & 5.45 & 0.13 & - & 2.09 & 0.78 & 1.00 & 3.00 & 6.65 & 2.31 & 55 & 22 \\
\hline $\mathrm{Cr}$ & 4.73 & 4.27 & -0.46 & 0.03 & 3.91 & 0.05 & - & 2.65 & 0.96 & 1.03 & 3.20 & 7.77 & 1.58 & 59 & 18 \\
\hline \multicolumn{16}{|c|}{ Profile 7 - LATOSSOLO AMARELO Eutrófico argissólico (LAe) } \\
\hline Ap & 4.61 & 4.07 & -0.54 & 0.09 & 13.11 & 0.15 & - & 2.35 & 0.92 & 0.97 & 2.75 & 6.94 & 11.03 & 60 & 19 \\
\hline $\mathrm{AB}$ & 4.97 & 4.28 & -0.70 & 0.04 & 5.86 & 0.03 & - & 2.77 & 1.02 & 1.25 & 2.70 & 7.52 & 1.04 & 64 & 21 \\
\hline Bw1 & 4.67 & 4.41 & -0.26 & 0.02 & 5.57 & 0.02 & - & 1.85 & 0.89 & 1.45 & 2.48 & 6.10 & 1.68 & 59 & 29 \\
\hline Bw2 & 4.56 & 4.25 & -0.31 & 0.02 & 4.31 & 0.01 & - & 2.15 & 0.91 & 1.30 & 1.93 & 5.89 & 2.69 & 67 & 25 \\
\hline
\end{tabular}

$\mathrm{EC}=$ electric conductivity; $\mathrm{TOC}=$ total organic carbono. 
The horizons presented great variations in base saturation, with values between $25 \%$ (horizon $\mathrm{AB}$ of P1) and 67\% (horizon Bw2 of P7) (Table 3). The low base saturation of P1 (LAd) was due to the chemical composition of the parent material that formed this soil and the leaching process of possible exchangeable bases that were solubilized by partial or total hydrolysis of primary minerals of the rock, forming dystrophic horizons. The high base saturation of P7 (LAe) can be attributed to the management applied in the study areas; these areas had record of anthropogenic action.

The low electrical conductivity found in all profiles indicates the low soluble salt contents. The soils of the Santana mountain range are deep, thus, the leaching occurring along the profile with rainfall remove excess salts, generating low electrical conductivity. Moreover, its parent material is dystrophic, thus, it provided primary minerals that contribute little with more soluble cations during the weathering process. No sodium content was found in the analyzed profiles. Sodium is the most soluble element among the exchangeable bases and was probably the first to be removed from the soil profile through leaching, which is part of the desilication pedogenetic process.

The highest total organic carbon (TOC) contents were found in surface horizons, ranging from $6.27 \mathrm{~g} \mathrm{~kg}^{-1}$ in P3 (RQo) to $16.70 \mathrm{~g} \mathrm{~kg}^{-1}$ in P1 (LAd). It decreased with depth; it is commonly observed in hot and dry soils, where soil organic matter is naturally concentrated in the first centimeters of the soil, with little evidence of organo -metallic complex migration to sub-surface horizons, typical of the podzolization process. The most superficial layers had higher TOC content due to the deposition of organic material on the soil surface. Most sandy soils, such as the Neossolos Quartzarênicos, have low maintenance of organic matter in the form of organo-metallic complexes due to many factors, mainly its low clay contents, which is important in the complexation process. This process can be more intense in Neossolos Quartzarênicos because of their low particle cohesion and contents of cementing agents (SALES et al., 2010).

The exchangeable potassium contents varied from $0.01 \mathrm{cmol}_{\mathrm{c}} \mathrm{kg}^{-1}$ (BA horizon of P1) to 0.15 $\mathrm{cmol}_{\mathrm{c}} \mathrm{kg}^{-1}$ (in the Ap horizon of P7). The low potassium contents found in the soil profiles may be due to an intense leaching because of the precipitation in the region, and the sandier texture of the soils.

The exchangeable aluminum content in the analyzed soils ranged from 0.01 (in the $\mathrm{AB}$ horizon of P4) to $1.45 \mathrm{cmol}_{\mathrm{c}} \mathrm{kg}^{-1}$ (in the Bw1 horizon of P7), with increases with depth. The higher presence of $\mathrm{Al}$ ${ }^{3+}$ in the subsurface was probably due to the weathering processes of the parent material; in addition, in the surface horizon, some of the aluminum contents may be associated with the organic matter and was not extracted by the $\mathrm{KCl}$ solution (COSCIONE et al., 1998).

In general, the available phosphorus contents were low; it is common in both Latossolos and Neossolos originated from arenites. The soil organic matter may be source of phosphorus or compete for soil adsorption sites, reducing phosphate fixation (ANDRADE et al., 2003). Exceptions to low phosphorus levels were found due to anthropogenic activities in some areas, which increased these phosphorus contents in the surface horizons of their soils (P4, P6, and P7).

Two principal components (Factor 1 and Factor 2) were generated for the chemical $(\mathrm{pH}$ in water, $\mathrm{pH}$ in $\mathrm{KCl}, \Delta \mathrm{pH}, \mathrm{CE}, \mathrm{TOC}, \mathrm{K}^{+}, \mathrm{Ca}{ }^{2+}$, exchangeable $\mathrm{Mg}^{2+}$ and $\mathrm{Al}^{3+}$, potential acidity, available $P$, Vvalue, $m$ value, effective CEC) and physical (sand, silt, and clay contents) attributes for the surface and subsurface horizons. The correlations between these components generated twodimensional ordering diagrams for the distinction between the evaluated profiles, and vector projection diagrams for the soil attributes that most influenced this distinction (Figure 2).

According to the diagrams, the surface layers of the soil profiles were similar, forming no specific groups but rather overlapping points. However, three groups were formed for the diagnostic horizons of the soil classes in the subsurface; even with overlapping points they can be distinguished in the ordering diagram (Figure 2a, b). The principal component analysis confirms the morphological characterization from field observations, denoting the importance of considering this information in the distinguishing of pedo-environments.

This analysis confirms the influence of soil attributes on the distinction of soil profiles and shows the importance of this tool to soil mapping, since the ordering diagram showed that the subsurface grouping of the profiles has a distribution tendency according to the profile location, i.e., the proximal profiles presented similar characteristics (Figure 2a, b). 


\section{Surface horizons}

(a)

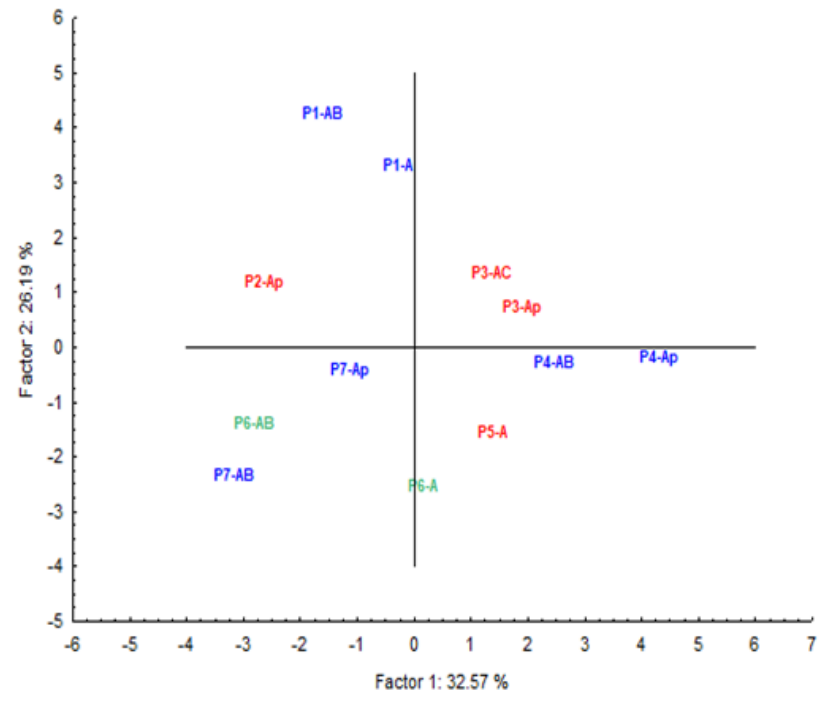

(c)

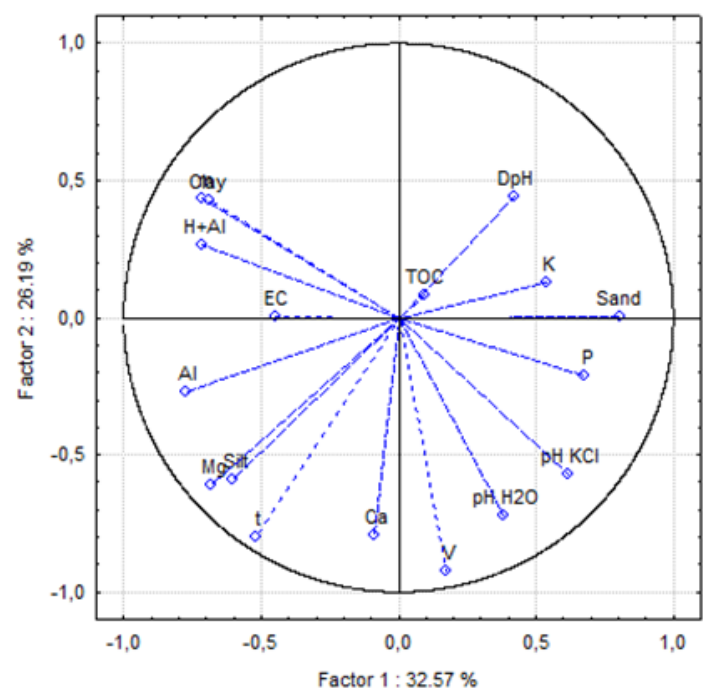

Subsurface Horizons

(b)

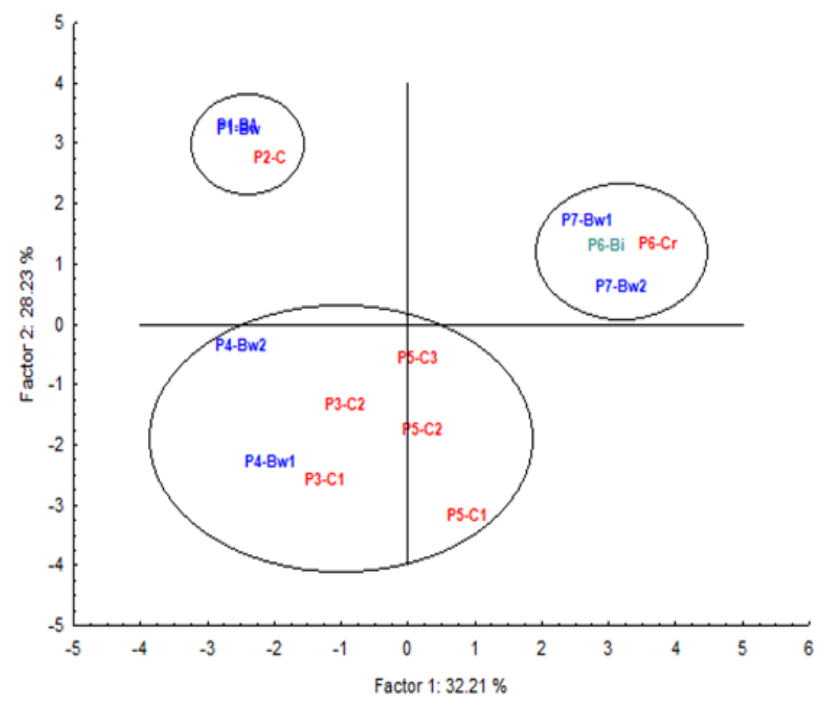

(d)

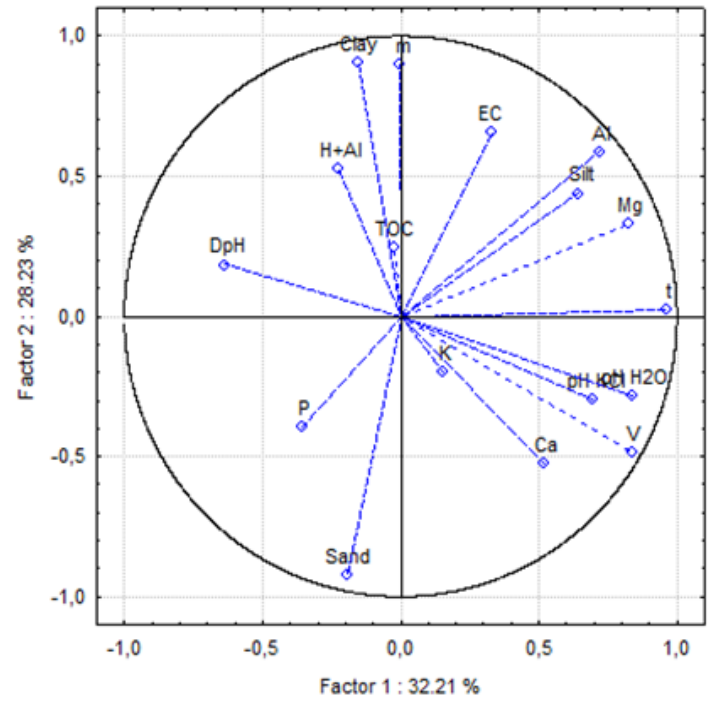

Figure 2. Ordering diagram of principal components (a and b) and vector projections of soil attributes (c and d) of surface and subsurface horizons of the representative soils of the Santana mountain range, Seridó Region, Rio Grande do Norte, Brazil.

Factor 1 explained $32.57 \%$ of the total variation of the attributes in the surface horizons, and the $\mathrm{Al}^{3+}$ content, potential acidity, aluminum saturation, and sand content presented the highest coefficients of correlation $(\geq|0.70|)$ (Table 4). Therefore, these soil attributes were more sensitive in distinguishing the surface horizons, denoting greater variation of these attributes (Figure 2c, d) in the representative soils of the Santana mountain range. Factor 2 explained $26.19 \%$ of the total variation of the attributes in the surface horizons (Table 4), with $\mathrm{pH}$ in water, $\mathrm{Ca}^{2+}$ content, base saturation, and effective CEC presenting the highest coefficients.

Regarding the attributes in the subsurface horizons of the analyzed profiles, Factor 1 explained $32.21 \%$ of the total variation, and $\mathrm{pH}$ in water, $\mathrm{Al}^{3+}$ content, $\mathrm{Mg}^{2+}$ content, base saturation, and effective CEC presented the highest coefficient of correlation (Table 4). Factor 2 explained $28.23 \%$ of the total variation, and aluminum saturation, sand content, and clay content presented the highest coefficient of correlation (Table 4). 
Table 4. Correlation coefficients of the principal components (Factors 1 and 2) for soil attributes in surface and subsurface horizons of representative soil profiles of the Santana mountain range, Seridó region, Rio Grande do Norte, Brazil.

\begin{tabular}{|c|c|c|c|c|}
\hline \multirow[t]{2}{*}{ Attribute } & \multicolumn{2}{|c|}{ Surface horizon } & \multicolumn{2}{|c|}{ Subsurface horizon } \\
\hline & Factor $1^{(1)}$ & Factor $2^{(1)}$ & Factor $1^{(1)}$ & Factor $2^{(1)}$ \\
\hline $\mathrm{pH} \mathrm{H} \mathrm{H}_{2} \mathrm{O}$ & 0.382 & -0.718 & 0.842 & -0.284 \\
\hline $\mathrm{pHKCl}$ & 0.616 & -0.572 & 0.698 & -0.294 \\
\hline$\Delta \mathrm{pH}$ & 0.418 & 0.443 & -0.634 & 0.184 \\
\hline $\mathrm{CE}$ & -0.445 & 0.002 & 0.329 & 0.656 \\
\hline COT & 0.098 & 0.083 & -0.022 & 0.244 \\
\hline $\mathrm{K}^{+}$ & 0.541 & 0.125 & 0.152 & -0.198 \\
\hline $\mathrm{Ca}^{2+}$ & -0.087 & -0.793 & 0.518 & -0.524 \\
\hline $\mathrm{Mg}^{2+}$ & -0.681 & -0.610 & 0.825 & 0.328 \\
\hline $\mathrm{Al}^{3+}$ & -0.775 & -0.271 & 0.720 & 0.588 \\
\hline $\mathrm{H}+\mathrm{Al}$ & -0.716 & 0.265 & -0.223 & 0.525 \\
\hline P & 0.678 & -0.214 & -0.359 & -0.392 \\
\hline V & 0.175 & -0.920 & 0.838 & -0.488 \\
\hline M & -0.712 & 0.434 & -0.001 & 0.901 \\
\hline $\mathrm{T}$ & -0.517 & -0.798 & 0.960 & 0.024 \\
\hline Sand & 0.803 & 0.007 & -0.191 & -0.923 \\
\hline Silt & -0.602 & -0.588 & 0.645 & 0.438 \\
\hline Clay & -0.691 & 0.427 & -0.153 & 0.905 \\
\hline Total variance $(\%)$ & 32.57 & 26.19 & 32.21 & 28.23 \\
\hline Accumulated variance $(\%)$ & 32.57 & 58.76 & 32.21 & 60.44 \\
\hline
\end{tabular}

${ }^{(1)}$ Factors $\geq|0.70|$ are significant (MANLY, 1994).

The most sensitive attributes of the Santana mountain range soils were found in both chemical (acidity and nutrient availability) and physical (sand and clay contents) characterizations. Thus, these attributes are important to distinguish environments and characterize soils. Santos et al. (2015) used multivariate analysis to evaluate the variability of attributes of Cambissolos in Lajes SC, Brazil, and found chemical and physical attributes as determinant factors for differentiating soil profiles, with organic carbon content, active and potential acidity, and base saturation as the most important chemical attributes; and pore volume, soil density, and total porosity as the most important physical attributes. Martins et al. (2010) used multivariate analysis in Luvissolos of the semiarid region of Pernambuco and found chemical and microbiological attributes as the most sensitive for the distinction of the environments.

\section{CONCLUSIONS}

The representative soil classes of the Santana mountain range are LATOSSOLO AMARELO Distrófico argissólico, LATOSSOLO AMARELO Eutrófico argissólico, NEOSSOLO QUARTZARÊNICO Órtico típico, NEOSSOLO LITÓLICO Eutrófico fragmentário, NEOSSOLO REGOLÍTICO Eutrófico típico, and CAMBISSOLO HÁPLICO Tb Eutrófico léptico.

The parent material responsible for the genesis of the main soils found in the study region is the same, arenite of the Paleogene period. It has a strong influence on the current constitution of the landscape when associated to two other important factors, the tropical hot and humid climate and flat relief of high altitudes of the region.

The morphological features of the evaluated soil profiles presented slight differences, which are shown by the soil colors and textures found. The yellow color predominates in all horizons with variations, showing lighter and greyish shades in Latossolos, and clearer and plain shades in Neossolos. Their textural classes varied from sand to sandy clay loam due to the clay translocation process to the subsurface.

The multivariate analysis established groups of representative soil profiles of the Santana mountain range through the distinction of physical and chemical attributes, mainly of subsurface diagnostic horizons.

\section{REFERENCES}

ALVARES, C. A. et al. Köppen's climate classification map for Brazil. Meteorologische Zeitschrift, Stuttgart, v. 22, n. 6, p. $711-728,2013$

ANDRADE, F. V. et al. Adição de ácidos orgânicos e húmico sem Latossolos e adsorção de fosfato. Revista Brasileira de Ciência do solo, Viçosa, v. 27, n. 6, p. 1003-1011, 2003.

ANGELIM, L. A. de A. et al. Geologia e recursos minerais do estado do rio grande do norte: texto explicativo dos mapas geológico e de recursos minerais do estado do rio grande do norte escala 1:500.000. 1. ed. Recife, PE: CPRM, 2006. 119 p.

COSCIONE, A. R.et al. Revisiting titration 
procedures for the determination of exchangeable acidity and exchangeable aluminium in soils. Communications in Soil Science Plant Analysis, New York, v. 29, n. 11-14, p. 1973-1982, 1998.

DONAGEMA, G. K. et al. Manual de métodos de análise de solos. 2. ed. rev. Rio de Janeiro: Embrapa Solos, 2011. 230 p. (Documentos / Embrapa Solos, ISSN 1517-2627; 132).

ERNESTO SOBRINHO, F. et al. Levantamento de reconhecimento semi-detalhado dos solos e caracterização do ambiente agrícola da Serra de Santana, Rio Grande do Norte. 1. ed. Mossoró, RN: Fundação Guimarães Duque. 1987. 125 p.

FERREIRA, M. M. et al. Mineralogia da fração argila e estrutura de Latossolos da região sudeste do Brasil. Revista Brasileira de Ciência do Solo, Viçosa, v. 23, n. 3, p. 507-514, 1999.

INSTITUTO BRASILEIRO DE GEOGRAFIA E ESTATÍSTICA - IBGE. Manual técnico da vegetação brasileira: sistema fitogeográfico, inventário das formações florestais e campestres, técnicas e manejo de coleções botânicas, procedimentos para mapeamentos. 2. ed. Rio de janeiro: IBGE- Diretoria de Geociências, 2012. 271 p.

LIBARDI, P. L. Dinâmica da água no solo. 1. ed. Piracicaba, SP: EDUSP, 2005, 335 p.

MANLY, B.F.J. Multivariate statistical methods. 2. ed. London, Chapman \& Hall, 1994. 215 p.

MARTINS, C. M. et al. Atributos químicos e microbianos do solo de área sem processo de desertificação no semiárido de Pernambuco. Revista Brasileira de Ciência do Solo, Viçosa, v 34, n. 6, p. 1883-1890, 2010.

NASCIMENTO, M. A. L.; FERREIRA, R. V. Projeto geoparques geoparque seridó - RN proposta. 1. ed. Recife, PE: CPRM, 2010. 59 p.

PEDRON, F. A. et al. Condutividade e retenção de água em Neossolos e saprolitos derivados de arenito. Revista Brasileira de Ciência do Solo, Viçosa, v. 35, n. 4, p 1253 - 1262, 2011.

SALES, L. E. et al. Qualidade física de Neossolo Quartzarênico submetido a diferentes sistemas de uso agrícola. Ciência e Agrotecnologia, Lavras, v. 34, n. 3, p 667-674, 2010.

SANTOS, J. C. B. et al. Caracterização de Neossolos Regolíticos da região semiárida do estado de
Pernambuco. Revista Brasileira de Ciência do Solo, Viçosa, v. 36, n. 3, p. 693-695, 2012.

SANTOS, R. D. et al. Manual de descrição e coleta de solo no campo. 6.ed. Viçosa, MG: Sociedade Brasileira de Ciência do Solo, 2013a. 100 p.

SANTOS, H.G. et al. Sistema brasileiro de classificação de solos. 3.ed. rev. e ampl. Brasília, DF: Embrapa, 2013b. 353 p.

SANTOS, P. G. et al. Agrupamento de pedons de Cambissolos Húmicos com base em atributos físicos e químicos utilizando a estatística multivariada. Revista Brasileira de Ciência do Solo, Viçosa, v. 39, n. 2, p. 350-360, 2015.

SILVA. M. L. N. et al. Topossequência de Neossolos na zona rural de Florânia, Rio Grande do Norte. ACSA - Agropecuária Científica no Semi-Árido, Patos, v. 10, n. 1, p. 22-32, 2014.

STATSOFT, INC. Statistica (Data Analysis Software System), Version 7, 2004.

YEOMANS, J. C.; BREMNER, J. M. A rapid and precise method for routine determination of carbon in soil. Communications in Soil Science Plant Analysis, New York, v. 19, n. 13, p. 1467-1476, 1988 . 